\title{
Editorial
}

\section{Approaching Leadership With a Follower Focus}

\author{
Michelle C. Bligh ${ }^{1}$ and Jeffrey C. Kohles ${ }^{2}$ \\ ${ }^{1}$ Drucker-Ito Graduate School of Management, School of Behavioral and Organizational Sciences, \\ Claremont Graduate University, Claremont, CA, USA, ${ }^{2}$ Center for Leadership Innovation \\ and Mentorship Building (CLIMB), College of Business Administration, California State University, \\ San Marcos, CA, USA
}

If a man aspires to the highest place, it is no dishonor to him to halt at the second, or even at the third.

\section{Cicero (46 B.C.E.)}

This introduction provides an overview of the special issue of Zeitschrift für Psychologie on "Followercentric Approaches to Leadership." The purposes of the special issue were to highlight new research on followers' needs, motivations, and attributions as critical aspects of the leadership relationship. In addition, we hope to have brought together a set of papers that represent new potential directions in research that stem from the examination of followers and followership. Many of the empirical findings and theoretical contributions in this special issue suggest that, just as not all leaders are the same, followers vary (sometimes dramatically) in their needs for certain types of leaders and leadership. In addition, followers differ in their susceptibility and responsiveness to certain types of leadership (e.g., adverse, charismatic, transformational, directive vs. supportive).

Over the past several decades, scholars have focused increased attention on followers and followership as a critical component of the leadership relationship. Anyone interested in leadership has likely considered the role of followers, whether active or passive, as fundamental to our understanding of the development, impact, and maintenance of leadership processes. A followercentric approach to leadership highlights new questions and new approaches. For example, how do individual characteristics and qualities of followers influence the development of leaders? What roles do followers' needs, values, wants, and preferences play in their tolerance or affinity for certain leadership styles? What types of leadership help in developing effective followership, and what types of followership help in developing effective leadership? These questions, among others, are the focus of this special issue.

This special issue therefore has a dual purpose. First, we wanted to highlight what types of research questions emerge from a followercentric approach. To this end, we sought empirical studies that considered: (1) followers' characteristics and potential biases that influence attributions of leadership, including attributions for organizational success and failure and the "romance of leadership" (Meindl, 1995); (2) the role of follower characteristics, perceptions, and motivations in interpreting leadership ratings, as well as the potential impact of situational factors such as the role of crisis and follower uncertainty or fear on these processes; and (3) the social construction of leadership, including social contagion processes and other interfollower processes that enhance or suppress leadership.

Second, we also hoped to include new theories and perspectives on the study of leadership and followership. The vast majority of studies of leadership are cross-sectional comparisons of leadership styles and followers' perceptions of leaders' styles; only within the last two decades have scholars begun to study the other side of the proverbial coin, focusing on followers' styles and the processes of followership. The studies in this special issue examine what it means to "reverse the lens" (Shamir, 2007) in leadership research by studying how followers perceive and enact their own roles in the co-production of leadership.

\section{Toward a Followercentric Approach}

The studies in this special issue make great headway in distinguishing among closely interrelated streams of research involving followership, followercentric approaches (Meindl, 
1995), and implicit followership theory (IFT; Sy, 2010). Carsten and Uhl-Bien, as well as Hoption, Christie, and Barling, tackle the meaning of followership as a socially defined role. They present data on how followers perceive followership - defined as the ways in which individuals construct and enact their roles in relation to leaders (Carsten, Uhl-Bien, West, Patera, \& McGregor, 2010; Uhl-Bien \& Pillai, 2007). Their approach can be distinguished from a followercentered approach, which focuses on how followers perceive leaders and leadership. Finally, IFT is concerned with how followers are perceived by leaders, or the prototypical schemas or types that leaders use to categorize followers. Grounded in an implicit theory approach, Sy (2010) explored the question "What is an effective follower?" His research yielded an 18-item measure of implicit followership that included hardworking, happy, and reliable as prototypic traits. These results confirm that followers can be thought of in a positive light, and showed that leaders view followers as prototypic when they are strong in industry as well as enthusiasm and demonstrate good citizenship, and as antiprototypic when they are insubordinate, incompetent, and high in conformity. It is a tribute to the growth of followercentric approaches that these three streams of research - followership, followercentered approaches, and IFT - are beginning to distinguish themselves as unique yet interrelated approaches to the study of followers.

\section{Overview of the Special Issue}

In organizing this collection, we begin with research that examines how followers create and define their roles and what it means to be labeled a follower. Carsten and Uhl-Bien (2012) point out that followers are active participants in the leadership process, and their influence is essential in the cocreation of leadership. However, as the authors highlight, little is known about how followers see themselves and their own roles in the leadership process, that is, a followership perspective (Uhl-Bien \& Pillai, 2007). Given that there is no leadership without followership (Collinson, 2006), additional research is necessary to uncover followers' beliefs regarding their own roles in the co-production of leadership.

Carsten and Uhl-Bien (2012) build on their previously validated measure of follower beliefs in the co-production of leadership, which assesses the extent to which followers see their role as partnering with leaders to identify strengths and weaknesses in work processes, identify and solve problems, and bring new and creative ideas to the table that enhance effectiveness. Their findings show that individuals with stronger co-production beliefs do not see followers as passive and deferent, but instead believe that followers are just as effectual as leaders, and can significantly bolster the outcomes of the leadership process through their participation. In addition, their results indicate that co-production beliefs are an important antecedent to upward communication behaviors such as voice and constructive resistance. They define constructive resistance as a form of objection or dissent that involves challenging a leader's request for action and working with the leader to devise a more appropriate plan. Further, they find that followers with weaker coproduction beliefs reported greater voice behavior when they perceived their leaders were high in consideration, had stronger perceptions of their overall relationship quality with their leader, and perceived an autonomous work climate. Conversely, followers with stronger co-production beliefs reported the same amount of voice behavior regardless of whether their context was favorable or unfavorable.

Next in this issue, Hoption, Christie, and Barling (2012) explore what it means to be labeled a follower. In two separate studies, they found evidence for negative effects of the follower label; specifically, participants who were labeled a follower (in Study 1), or self-labeled as followers in their jobs (in Study 2) reported lower positive affect, and in turn, fewer extra-role behaviors. These findings suggest that followers might be at risk for reinforcing negative stereotypes by avoiding opportunities to showcase their abilities and demonstrate their independence. This research also highlights the importance of organizational labels, which facilitate sense-making and guide employee interactions by providing cues for how to organize and understand experiences. The authors' evidence suggests that the label "follower" primarily reflects passivity, obedience, and submission (e.g., never asking questions of leaders and excessive agreement with leaders).

Contemporary leadership approaches argue that follower involvement best positions followers as active partners or collaborators in leadership (e.g., Shamir, 2007; Uhl-Bien, 2006). Active followership emphasizes the ways in which followers encourage and challenge leaders, and demonstrate independent thought and critical thinking (see Chaleff, 1995; Kelley, 1992); essentially, active followership amounts to effective followership. However, Hoption et al. (2012) point out that both scholars and practitioners are unaccustomed to thinking about followership as a skill. As a result, the idea that there are varying qualities of followership upon which we can judge effectiveness is somewhat of a foreign concept. Second, the devaluation of followers throughout history is entrenched in our belief systems and stereotypes. Hoption et al. suggest that until a shared definition of effective followership is achieved, the current state of followership connotations remains predominantly negative. Their findings from two studies suggest that in practice, followers' lack of extra-role behaviors might hinder appreciation of followers in organizations. In essence, the follower label is associated with a lack of extra-role behaviors, which only perpetuates the stereotype that followers lack initiative and need direction. In the interest of weakening that stereotype, both researchers and practitioners must work to foster active followership and extra-role behaviors.

In addition, the authors note that there is potential for leaders to also elevate the follower label and challenge its negative stereotypes. Inspired by the notion that all organizational members are simultaneously leading and following (Weick, 2007), leaders should work to combat the belief that only those who cannot lead or have lowly status should occupy follower roles. Doing so may prompt followers to feel more positively about their roles and encourage extra-role behaviors. 
While the first two papers in this special issue focus on what it means to enact the follower role and be labeled as such, the next two papers specifically highlight how individual differences interact with the follower label.

Ehrhart (2012) examines follower characteristics that are particularly relevant to how followers perceive and react to leaders. Although numerous follower characteristics have been studied, the author argues that follower self-concept may be particularly important. Previous studies (Lord \& Brown, 2001, 2004; Lord, Brown, \& Frieberg, 1999) have emphasized the importance of leaders targeting their behavior toward the level of followers' self-identity, as well as pointing out how followers' self-concepts are activated when leader behavior is aligned with followers' values. Additionally, Shamir, House, and Arthur's (1993) self-concept based theory of charismatic leadership highlights that charismatic leaders have profound effects on their followers by linking goals to followers' self-concepts. Ehrhart builds on this past research by investigating how followers' selfconcept and their implicit leadership theories (ILTs) relate to initial preferences for leadership. Ehrhart hypothesizes that followers' self-concepts will predict their conceptualization of an ideal leader as well as their preferences for specific leadership styles. Each follower has an ILT, or a conceptualization of an ideal leader, that he or she brings to the leadership encounter, and which may vary depending on the follower and their unique personality, values, and other characteristics. When a follower encounters a leader, it is the degree of match between the follower's ILT and the leader's behavior that drives the follower's reactions to the leader and expectations for the leadership relationship (Lord, Foti, \& De Vader, 1984). Ehrhart's results indicate that a follower's independent self-construal predicts charismatic leader preference, perhaps because these types of followers are most interested in a leader who will allow them to achieve their goals and express their personalities. These findings support the basic notion that followers vary in their conceptualizations of their ideal leaders and in their reactions to identical leadership behaviors. Therefore, much like fit with the job and work group, the degree of fit between followers' self-concepts and a manager's leadership style will have a significant impact on the relationship that develops between follower and leader. In sum, how followers view themselves is related to their conception of an ideal leader, which subsequently impacts how followers react to specific leadership styles.

The next paper in this special issue similarly deals with the role of follower characteristics and ILTs, but this time in the case of negative or adverse leadership. Peus, Braun, and Frey (2012) note that followers often appear as passive bystanders confronted with petty tyrants rather than as active contributors to toxic leadership. They argue that adverse leadership arises when followers (1) perceive their leader to violate leadership prototypes or to concur with antiprototypes, and (2) attribute this violation to internal stable conditions within the leader, even though (3) the leader had no intentions to cause harm. This examination of adverse leadership thus focuses on the role of followers' implicit leadership theories and attributions in co-constructing negative leadership, particularly when the negative leadership behaviors were not meant to be harmful. The authors point out that negative leadership and its consequences can arise as a mere result of follower perceptions - even if the leader did not act with any intention to cause harm. Followers can perceive their leaders as adverse if they exhibit behaviors that run counter to the followers' leadership prototypes, or if they exhibit behaviors that are congruent with followers' leadership antiprototypes. Common aspects of antiprototypes are, for example, masculine and pushy behaviors, which leaders may demonstrate with good intentions, such as for "rallying the troops." Followers' personality traits such as self-esteem and attribution styles thus hold the potential to either buffer or fuel the effects of adverse leadership.

Peus et al. (2012) also suggest that the probability of adverse leadership emergence increases with social distance in groups. In addition to highlighting the role that attribution processes play in increasing negative follower perceptions, the authors also explore how these perceptions might spread from an individual to the group through social and emotional contagion to ultimately impact organizational outcomes. The authors call for future investigations of how followers respond to adverse leadership and how its emergence can be prevented.

Similarly, in the final paper, Lapierre, Bremner, and McMullan (2012) consider the complementary roles of employees and managers in the emergence of charismatic leadership, but focus on how both the follower role (passive vs. active) and a manager's IFTs interact to co-create personalized versus socialized charismatic leadership. The authors theorize that followership behaviors influence managers' positive affect and psychological empowerment, which in turn drive the degree to which managers manifest charismatic leadership inclinations. In other words, followership behaviors, whether passive or proactive, can be viewed as situational variables that influence the degree to which a leader displays charismatic leadership.

The authors specifically note that passive followership involves strict obedience and high deference to one's leader, as well as refraining from questioning the leader's ideas or directions. Such behaviors are consistent with the very traditional view of followers as less gifted, highly loyal, and unquestioning. Proactive followers voice their ideas and concerns to their leader without being asked, and constructively challenge their leader's ideas or decisions if they are not consistent with the group's mission. This is consistent with the notion that employees enter into a relationship with their manager with preexisting needs, beliefs, and values. Lapierre et al. (2012) present a number of propositions for future research. Specifically, they posit that because of their more proactive IFTs, managers with a stronger predisposition for socialized charismatic leadership will experience more positive affect and feel more empowered when faced with proactive followers. Similarly, because of their more passive IFTs, managers with a stronger predisposition for personalized charismatic leadership will experience more positive affect and feel more empowered when faced with more passive followers. In sum, this paper highlights followers as co-creators of charismatic leadership by explaining the influence of employees' followership behaviors on 
managers' display of personalized and socialized charismatic leadership behavior.

We hope that this collection of papers extends the research knowledge base on followercentric approaches from all three perspectives - the interrelated streams of research involving followership, followercentric approaches, and implicit followership theory. We also hope that these studies will: (a) stimulate more research on followers and followership; (b) draw attention to new research questions that emerge from examining leadership from the perspective of followers; and (c) encourage more evaluation of both leadership and followership as integrally related processes.

\section{References}

Carsten, M. K., \& Uhl-Bien, M. (2012). Follower beliefs in the co-production of leadership: Examining upward communication and the moderating role of context. Zeitschrift für Psychologie, 220, 210-220. doi: 10.1027/2151-2604/ a000115

Carsten, M. K., Uhl-Bien, M., West, B. J., Patera, J., \& McGregor, R. (2010). Exploring social constructions of followership: A qualitative study. The Leadership Quarterly, $21,543-562$.

Chaleff, I. (1995). The courageous follower: Standing up to and for our leaders. San Francisco, CA: Berrett-Koehler.

Collinson, D. (2006). Rethinking followership: A poststructuralist analysis of follower dynamics. The Leadership Quarterly, 17, 179-189.

Ehrhart, M. G. (2012). Self-concept, implicit leadership theories, and follower preferences for leadership. Zeitschrift für Psychologie, 220, 231-240. doi: 10.1027/2151-2604/ a000117

Hoption, C., Christie, A., \& Barling, J. (2012). Submitting to the follower label: Followership, positive affect and extra-role behaviors. Zeitschrift für Psychologie, 220, 221-230. doi: 10.1027/2151-2604/a000116

Kelley, R. E. (1992). The power of followership: How to create leaders people want to follow and followers who lead themselves. New York, NY: Doubleday.

Lapierre, L. M., Bremner, N. L., \& McMullan, D. A. (2012). Strength in numbers: How employees' acts of followership can influence their manager's charismatic leadership behavior. Zeitschrift für Psychologie,, 220, 251-261. doi: 10.1027/ 2151-2604/a000119

Lord, R. G., \& Brown, D. J. (2001). Leadership, values, and subordinate self-concepts. The Leadership Quarterly, 12, $133-152$.

Lord, R. G., \& Brown, D. J. (2004). Leadership processes and follower self-identity. Mahwah, NJ: Erlbaum.

Lord, R. G., Brown, D. J., \& Freiberg, S. J. (1999). Understanding the dynamics of leadership: The role of follower selfconcepts in the leader/follower relationship. Organizational Behavior and Human Decision Processes, 78, 167-203.
Lord, R. G., Foti, R., \& De Vader, C. (1984). A test of leadership categorization theory: Internal structure, informational processing, and leadership perceptions. Organizational Behavior and Human Performance, 34, 343-378.

Meindl, J. R. (1995). The romance of leadership as a followercentric theory: A social constructionist approach. The Leadership Quarterly, 6, 329-341.

Peus, C., Braun, S., \& Frey, D. (2012). Despite leaders' good intentions? The role of follower attributions in adverse leadership - a multilevel model. Zeitschrift für Psychologie, 220, 241-250. doi: 10.1027/2151-2604/a000118

Shamir, B. (2007). From passive recipients to active coproducers: Followers' roles in the leadership process. In B. Shamir, R. Pillai, M. C. Bligh, \& M. Uhl-Bien (Eds.), Follower-centered perspectives on leadership: A tribute to the memory of James R. Meindl (pp. ix-xxxix). Greenwich, $\mathrm{CT}$ : Information Age.

Shamir, B., House, R. J., \& Arthur, M. B. (1993). The motivational effects of charismatic leadership: A self-concept based theory. Organization Science, 4, 577-594.

Sy, T. (2010). What do you think of followers? Examining the content, structure, and consequences of implicit followership theories. Organizational Behavior and Human Decision Processes, 113, 73-84.

Uhl-Bien, M. (2006). Relational leadership theory: Exploring the social processes of leadership and organizing. The Leadership Quarterly, 17, 654-676.

Uhl-Bien, M., \& Pillai, R. (2007). The romance of leadership and the social construction of followership. In B. Shamir, R. Pillai, M. C. Bligh, \& M. Uhl-Bien (Eds.), Follower centered perspectives on leadership: A tribute to the memory of James R. Meindl (pp. 187-209). Greenwich, CT: Information Age.

Weick, K. (2007). Romancing, following, and sensemaking. In B. Shamir, R. Pillai, M. C. Bligh, \& M. Uhl-Bien (Eds.), Follower - centered perspectives on leadership: A tribute to the memory of James R. Meindl (pp. 279-291). Greenwich, $\mathrm{CT}$ : Information Age.

Michelle C. Bligh

Drucker-Ito Graduate School of Management

School of Behavioral and Organizational Sciences

Claremont Graduate University

123 East Eighth Street

Claremont, CA 91711

USA

Tel. +1 909 607-3715

Fax +1 909 621-8905

E-mail michelle.bligh@cgu.edu 